\section{表面張力による錠剤の 崩壊*}

\section{Tablet Disintegration by Surface Tension}

生の殿粉粒は昔から経験的に優れた崩壊剂として知られているが，その崩壞の理由は水を吸つて膨潤する為と

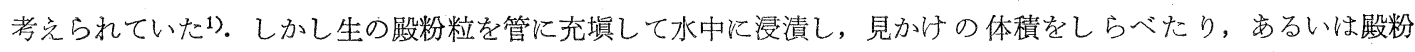
粒を顕微鏡下で水で濡らしてみても殿粉の膨潤は観察できない.殿粉の甚しい膨潤は錠剤の崩壊時間として期待 されているような短い時間内に招こることは無いのである2). Curlin は染料の溶液が速かにアスピリン錠の内部 に浸漬することを観察して，崩壊の原因は毛管現象によるものであるらと述べている．毛管現象によつて何故に 崩壊が行われるか Curlin は触れていないのであるが，著者はアスピリンと殿粉の模型を考兄て錠剤崩填の原因 そついて類推を行いたい。

錠剤は製造の過程に扔いて粘着剤, 滑剤などを含み, 湿潤, 練合, 乾燥等の操作を経るので複雑な要素を含ん でいる、したがつて錠剤をそのまま対象とせず，考光方を単純化する為に主成分であるアスピリンと崩壞剤の殿 粉だけについて崩壊の模型的概念をたて，錠剤崩壊の類推としたい。

アスピリンと殿粉を湿合すると殿粉はアスピリンの表面によく付着する。これが水中で離れる性質のるのであ れば，崩壞の原因は考忩易いのであるが，両者が水中に没入した模型では反詨の結果になる.
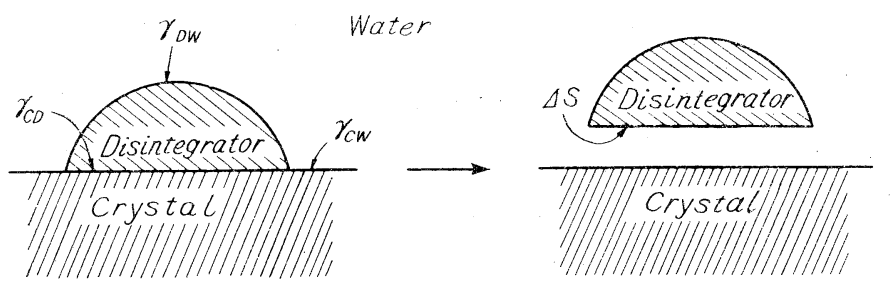

Fig. 1. Schema of Separating the Disintegrator from Crystal in Water

$\gamma_{C W}:$ Interfacial tension between crystal and water $\gamma_{D W}:$ Interfacial tension between disintegrator and water $\gamma_{C D}:$ Interfacial tension between crystal and disintegrator $\Delta S$ : Area of adhesion between crystal and disintegrator

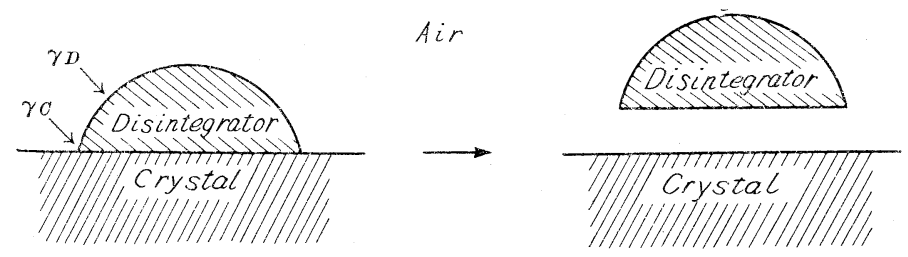

Fig. 2. Schema of Separating the Disintegrator from Crystal in Air $\gamma_{C}:$ Surface tension of crystal $\gamma_{D}:$ Surface tension of disintegrator

Fig. 1 のよ5にアスピリンの結晶と崩壊剂が接触している模型を考学ると, 水中で結晶と崩壞剤とが付着状態 から分離するときの Gibbs の自由エネルギーの增加量 $\Delta G$ は

* 日本薬学会関東支部例会 $(1957$ 年 9 月第 2 例会) にて発表.

1) 例党ば Remington's Practice of Pharmacy 10th Ed. 1382; C. B. Granberg, B.E. Benton: J. Am. Pharm. Assoc., Sci. Ed. 38, 648(1949).

2) L.C. Curlin: J. Am. Pharm. Assoc., Sci. Ed. 44, 16(1955); 中川l : 工化 50, 115(1947). 


$$
\begin{aligned}
& \Delta G=\gamma_{C W} \Delta S+\gamma_{D W} \Delta S-\gamma_{C D} \Delta S \\
& \therefore \frac{\Delta G}{\Delta S}=\gamma_{C W}+\gamma_{D W}-\gamma_{C D} \\
& \text { こに } \quad \gamma_{l}: \text { 水の表面張力 } \\
& \theta_{C}: \text { 結晶と水との接触角 } \\
& \theta_{D}: \text { 崩壊剂と水との接触角 }
\end{aligned}
$$

とすれば Young の関係から

$$
\frac{\Delta G}{\Delta S}=\left(\gamma_{C}+\gamma_{D}-\gamma_{C D}\right)-\gamma_{l}\left(\cos \theta_{C}+\cos \theta_{D}\right)
$$

一方 Fig. 2 のよ5に空気中で付着している結晶と崩壊剤を引き離すに要する Gibbsの自由エネルギーの增加 量 $\Delta G^{\prime}$ は

$$
\begin{aligned}
& \Delta G^{\prime}=\gamma_{O} \Delta S+\gamma_{D} \Delta S-\gamma_{C_{D}} \Delta S \\
& \therefore \frac{\Delta G^{\prime}}{\Delta S}=\gamma_{C}+\gamma_{D}-\gamma_{C D} \\
& \frac{\Delta G}{\Delta S}=\frac{\Delta G^{\prime}}{\Delta S}-\gamma_{l}\left(\cos \theta_{C}+\cos \theta_{D}\right) \\
& \left.\theta_{C}=102 \sim 110^{\circ 3}\right) \\
& \text { 今, アスピリンの場合 } \\
& \theta_{D}=80 \sim 85^{\circ 3} \text { ) } \\
& \frac{\Delta G}{\Delta S}>\frac{\Delta G^{\prime}}{\Delta S}
\end{aligned}
$$$$
\text { (2), (3)より }
$$

殿粉の場合

であるから (4)より

となり，アスピリンと殿粉が付着しているときは水中で両者を引き離す方が空気中で引き離すより仕事の量が大 きいので空気中で付着している殿粉粒が水中で自ら離れることはないわけである.

次にアスピリンと殿粉の間に気液界面が存在する模型を考える．殿粉はアスピリンに付着しているのであるが， 錠剤には空陌があつて水はその間に浸漬してゆくので，空裳を距てて両者が存在する模型を考えることが出来る。 便宜上模型ではアスピリンも殿粉も板状とする.

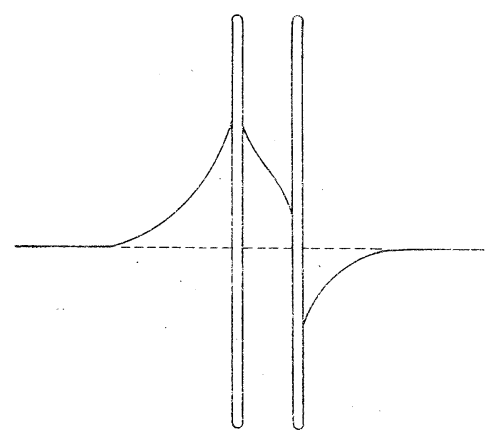

Fig. 3. Meniscus of Two Plates

One plate is wettable and the other is not wettable. Both plates are situated in close proximity.

一方の板が濡れ他方が濡れない場合には网者閒の距離によつて毛管上升が行われるとき (Fig. 3) と，行われな

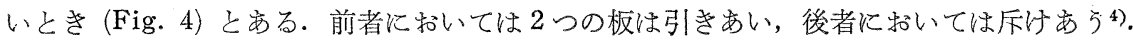

従つてアスピリン錠の崩壞に際して空隙に浸漬して行く水は空隙が斥けあう大きさの所に達したとき，これを 破壞するものであると類推したい。

Tokyo Plant, Takeda Pharmaceutical Industries, Ltd. 763 3-chome, Takadaminami-cho, Toshima-ku, Tokyo. November 11, 1958

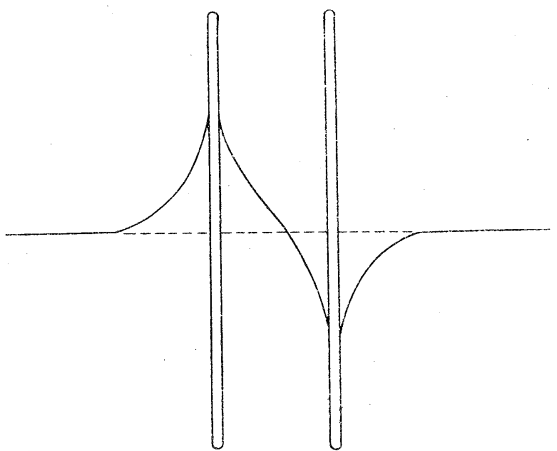

Fig. 4. Distance of Two Plates is longer than in Fig. 3.

3) 松丸：本誌 79, 66(1959).

4) J.H. Pointing, J.J. Thomson : “Textbook of Physics. Properties of Matter ” 153(1924). 